\title{
Therapeutic effects of a taurine-magnesium coordination compound on experimental models of type 2 short QT syndrome
}

\author{
Meng-yao AN ${ }^{1}$, Kai SUN ${ }^{1}$, Yan $\mathrm{LI}^{1}$, Ying-ying PAN ${ }^{1}$, Yong-qiang $\mathrm{YIN}^{1}$, Yi KANG ${ }^{1}$, Tao SUN ${ }^{2}$, Hong WU ${ }^{1}$, Wei-zhen GAO ${ }^{1}$, \\ Jian-shi LOU ${ }^{1, *}$ \\ ${ }^{1}$ Department of Pharmacology, College of Basic Medical Sciences, Tianjin Medical University, Tianjin 300070, China; ${ }^{2}$ State Key \\ Laboratory of Medicinal Chemical Biology, Nankai University, Tianjin 300071, China
}

\begin{abstract}
Short QT syndrome (SQTS) is a genetic arrhythmogenic disease that can cause malignant arrhythmia and sudden cardiac death. The current therapies for SQTS have application restrictions. We previously found that $\mathrm{Mg} \cdot\left(\mathrm{NH}_{2} \mathrm{CH}_{2} \mathrm{CH}_{2} \mathrm{SO}_{3}\right) 2 \cdot \mathrm{H}_{2} \mathrm{O}$, a taurine-magnesium coordination compound (TMCC) exerted anti-arrhythmic effects with low toxicity. In this study we established 3 different models to assess the potential anti-arrhythmic effects of TMCC on type 2 short QT syndrome (SQT2). In Langendorff guinea pig-perfused hearts, perfusion of pinacidil $(20 \mu \mathrm{mol} / \mathrm{L})$ significantly shortened the QT interval and QTpeak and increased rTp-Te $(P<0.05 \mathrm{vs}$ control). Subsequently, perfusion of TMCC (1-4 mmol/L) dose-dependently increased the QT interval and QTpeak ( $P<0.01$ vs pinacidil). TMCC perfusion also reversed the $\mathrm{rTp}$-Te value to the normal range. In guinea pig ventricular myocytes, perfusion of trapidil (1 mmol/L) significantly shortened the action potential duration at $50 \%\left(\mathrm{APD}_{50}\right)$ and $90 \%$ repolarization $\left(\mathrm{APD}_{90}\right)$, which was significantly reversed by TMCC (0.01-1 mmol/L, $P<0.05$ vs trapidil). In HEK293 cells that stably expressed the outward delayed rectifier potassium channels $\left(I_{\mathrm{Ks}}\right)$, perfusion of TMCC $(0.01-1 \mathrm{mmol} / \mathrm{L})$ dose-dependently inhibited the IKs current with an IC $\mathrm{C}_{50}$ value of $201.1 \mu \mathrm{mol} / \mathrm{L}$. The present study provides evidence that TMCC can extend the repolarization period and inhibit the repolarizing current, $I_{\mathrm{Ks}}$, thereby representing a therapeutic candidate for ventricular arrhythmia in SQT2.
\end{abstract}

Keywords: short QT syndrome; taurine-magnesium coordination compound; pinacidil; trapidil; Langendorff guinea pig-perfused hearts; ventricular myocytes; $I_{\mathrm{Ks}}$; refractory period

Acta Pharmacologica Sinica (2018) 39: 382-392; doi: 10.1038/aps.2017.86; published online 26 Oct 2017

\section{Introduction}

QT interval prolongation due to disorders of ventricular repolarization results in long QT syndrome (LQTS), which has been extensively investigated. In contrast, little is known about QT interval shortening due to genetic disorders, leading to short QT syndrome (SQTS), a genetic arrhythmogenic disease.

SQTS was first discovered by Gussak et al ${ }^{[1]}$ in 2000 as a new clinical syndrome related to sudden cardiac death. SQTS is characterized by an abnormally short QT interval, paroxysmal atrial fibrillation, and life-threatening ventricular fibrillation (VF) due to accelerated cellular repolarization. Although the morbidity of SQTS is not as high as LQTS, SQTS can cause malignant arrhythmia and sudden cardiac death. Researchers

\footnotetext{
* To whom correspondence should be addressed.

E-mail jianshilou@126.com (Jian-shi LOU)

Received 2017-03-25 Accepted 2017-05-19
}

have focused on the pathogenesis and therapy of SQTS.

SQTS can be classified into congenital (c) SQTS and acquired (a) SQTS based on their different causes. CSQTS is a hereditary disease. To date, mutations in seven genes (KCNH2, KCNQ1, $K C N J 2, C A C N 1 A c, C A C N B 2 b, C A C N A 2 D 1$, and $S C N 5 A)$ have been identified as responsible for types 1 to 7 of SQTS (SQT1SQT7 $)^{[2-4]}$. aSQTS is an acquired cardiac ion channel disease, and it is more common than cSQTS. aSQTS is caused by acquired triggers such as QT interval shortening and can also lead to fatal arrhythmia in specific clinical conditions. The related causes of aSQTS are digitalis poisoning, hypercalcemia, hyperkalemia, acidosis, acute myocardial infarction hyperacute phase, tachycardia, variant angina pectoris, cerebrovascular accident, omethoate poisoning, hyperthyroidism, hypothermia, megatemperature, hormonal drugs, ATP-sensitive potassium channel opener and anti-epileptic drugs such as rufinamide, and nervous system imbalance ${ }^{[5-8]}$.

Therapies for SQTS include implantation of an implantable 
cardioverter defibrillator (ICD) $)^{[9]}$ and anti-arrhythmic drugs (quinidine $^{[10]}$, disopyramide ${ }^{[11]}$, nifekalant ${ }^{[12]}$, isoproterenol ${ }^{[13]}$, carvedilol, and metoprolol $\left.{ }^{[14]}\right)$. However, all of these therapies have application restrictions. For example, ICD is not suitable for children. Furthermore, few reports have been published on effective pharmacological treatments for SQT2 and its electrophysiological mechanism.

Current research on SQTS is focused on the discovery of new therapeutic factors (new mutations, susceptibility to disease and drugs, etc) and effective therapeutic drugs. SQTS models are often used in the development of new drugs. Current models include gene-mutant and drug-induced models of SQTS. The drug-induced model is more widely used in experimental studies, as it can be studied at the cellular level as well as in isolated hearts and whole experiments. However, gene mutations can only be studied at the cellular level. Pinacidil has been employed to establish an SQTS model in intact rabbit hearts ${ }^{[15]}$, guinea pig hearts ${ }^{[16]}$, and wedge preparations $^{[17]}$. Pinacidil shortens the QT internal and abbreviates the action potential duration (APD). Several studies have employed pinacidil to generate SQTS models ${ }^{[18,19]}$. Another drug, trapidil, shortens the APs in the ventricular myocytes of isolated chick hearts ${ }^{[20]}$ and abbreviates APD by increasing the potassium outward current $\left(I_{\mathrm{K}}\right)$ in rabbit sinoatrial node cells ${ }^{[21]}$. Moreover, trapidil does not affect $I_{\mathrm{Kr}}$, and it selectively enhances $I_{\mathrm{Ks}}$ (the altered current in SQT2) ${ }^{[2]}$. Therefore, in this study, we chose pinacidil and trapidil to establish pharmacological models of SQT2.

Previous studies have demonstrated that taurine and magnesium have protective effects against arrhythmias ${ }^{[23,24]}$. In our preliminary studies, we synthesized a taurine-magnesium coordination compound (TMCC; molecular formula, $\mathrm{Mg}\left[\mathrm{NH}_{2} \mathrm{CH}_{2} \mathrm{CH}_{2} \mathrm{SO}_{3}\right]_{2} \cdot \mathrm{H}_{2} \mathrm{O}$; molecular weight, 290.04; Figure 1). Preliminary analysis revealed that TMCC has specific antiarrhythmic effects and very low toxicity. TMCC has been shown to markedly inhibit delayed L-type $\mathrm{Ca}^{2+}$ currents, rectifier $\mathrm{K}^{+}$currents, and sodium currents in guinea pig ventricular cardiomyocytes $^{[25,26]}$. Our preliminary study demonstrated that TMCC could prevent LQTS. However, whether TMCC has anti-arrhythmic effects for SQT2 is not known. To our knowledge, there is no report of a drug that not only prevents LQTS but also has anti-arrhythmic effects for SQTS.

In this study, we focused on developing an SQT2 therapy based on the gain of potassium channel function to enhance the slow component of the outward delayed rectifier potas-

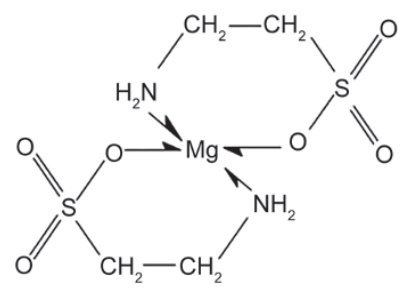

Figure 1. Structure of the taurine-magnesium coordination compound (TMCC). sium current, $I_{\mathrm{Ks}}$. Two drugs - pinacidil and trapidil-were used to establish pharmacological models of SQT2. We aimed to explore the potential anti-arrhythmic effect of TMCC on SQT2 and elucidate its predominant mechanism. The main objective of our study was to address the following questions: (1) does TMCC have an effect on the QT interval, refractory period, or transmural dispersion of ventricular repolarization (TDR) of a heart isolated from a guinea pig SQT2 model, and (2) what is mechanism of the potential anti-arrhythmic effect of TMCC on SQT2?

\section{Materials and methods Animals}

Healthy adult male guinea pigs weighing 250-300 g were purchased from the Experimental Animals Research Institute of the Military Medical Science Academy of China (SPF grade, SCXK-2014-0012).

The animals were cared for according to the guidelines of the Committee for the Purpose of Control and Supervision of Experiments on Animals in China. The experimental protocol was approved by the Laboratory Animal Care and Use Ethical Committee of Tianjin Medical University (Tianjin, China) and followed the Guide for the Care and Use of Laboratory Animals published by the U.S. National Institutes of Health (NIH Publication № 852-3, revised 1996).

\section{Drugs}

TMCC was kindly provided by the China Tianjin Medical University (Batch No 100031) and dissolved in distilled water to prepare a stock solution $(100 \mathrm{mmol} / \mathrm{L})$. Trapidil and pinacidil (Sigma-Aldrich, St Louis, MO, USA) were dissolved in dimethyl sulfoxide (DMSO; $10 \mathrm{mmol} / \mathrm{L}$ and $30 \mathrm{mmol} / \mathrm{L}$ stock solutions, respectively). The vehicle (distilled water or DMSO) had no measurable effect on $I_{\mathrm{Ks}}, \mathrm{AP}$, and the electrocardiogram (ECG) at maximal concentrations $(0.1 \%)$ used. Stock solutions were stored at $4{ }^{\circ} \mathrm{C}$.

\section{Preparation of the hearts for perfusion and ECG recording}

The animal was anesthetized with $1 \mathrm{~mL}$ of $2 \%$ pentobarbital sodium $(30 \mathrm{mg} / \mathrm{kg}$, ip) and heparin (1000 U, ip). The heart was removed and immediately placed in ice-cold KrebsHenseleit solution (composition in mmol/L: $118.06 \mathrm{NaCl}, 4.69$ $\mathrm{KCl}, 1.18 \mathrm{KH}_{2} \mathrm{PO}_{4}, 1.18 \mathrm{MgSO}_{4}, 25 \mathrm{NaHCO}_{3}, 11.11$ glucose, 2.5 $\mathrm{CaCl}_{2} ; \mathrm{pH}$ was adjusted to 7.4 using $\mathrm{HCl}$ ). The aorta was cannulated, and the heart was attached to a vertical Langendorff apparatus (Chengdu Instrument Factory, Chengdu, China) and retrogradely perfused with warm $\left(37^{\circ} \mathrm{C}\right) \mathrm{Krebs}-\mathrm{Henseleit}$ solution. The perfusate was equilibrated with $95 \% \mathrm{O}_{2}$ and $5 \%$ $\mathrm{CO}_{2}\left(\mathrm{pH} 7.4,37^{\circ} \mathrm{C}\right)$. The perfusion pressure was maintained at $80 \mathrm{~mm} \mathrm{H}_{2} \mathrm{O}$. The two electrodes to record the ECG were placed in the apical and aortic roots of the guinea pig heart. After successfully establishing the heart perfusion model, the heart was stabilized and equilibrated for $30 \mathrm{~min}$ before the data were recorded. The electrocardiogram was recorded using a BIOPAC/MP150 multi-channel physiological signal analyzer (BioPac Goleta, CA) and the AcqKnowledge 4.1 soft- 
ware. After the heart was perfused with normal K-H solution for $20 \mathrm{~min}$, SQT2 was simulated by infusion of pinacidil (20 $\mu \mathrm{mol} / \mathrm{L}$ ) over a period of $20 \mathrm{~min}$, and measurements were repeated. Then, $\operatorname{TMCC}(1,2$, and $4 \mathrm{mmol} / \mathrm{L})$ was infused for $20 \mathrm{~min}$. All electrocardiographic parameters reached equilibrium within $10 \mathrm{~min}$, and 10 consecutive beats of RR interval, QRS interval, and QT interval were blindly and randomly recorded. In addition, the intervals from $\mathrm{T}$-wave peak to $\mathrm{T}$-wave end $(\mathrm{Tp}-\mathrm{Te})$ and $\mathrm{Q}$-wave to $\mathrm{T}$-wave peak $\left(\mathrm{QT}_{\text {peak }}\right)$ were determined. The Tp-Te/QT ratio ( $\mathrm{rTp}-\mathrm{Te}$ ) was calculated. The ECG at each drug concentration was recorded at least 10 times on each heart isolated from different guinea pigs.

\section{Cell culture}

Single ventricular myocytes were enzymatically dissociated from the hearts of adult guinea pigs. The heart was quickly excised with a sufficient length of the aorta, which was placed on the tip of a cannula in a Langendorff apparatus. The heart was perfused with calcium-free perfusion buffer $\mathrm{A}$ (in $\mathrm{mmol} / \mathrm{L}: 136 \mathrm{NaCl}, 5.4 \mathrm{KCl}, 1.5 \mathrm{CaCl}_{2}, 0.33 \mathrm{~K}_{2} \mathrm{HPO}_{4} \cdot 2 \mathrm{H}_{2} \mathrm{O}, 1.0$ $\mathrm{MgSO}_{4} \cdot 7 \mathrm{H}_{2} \mathrm{O}, 10$ glucose, and 10 HEPES; $\mathrm{pH}$ was adjusted with $\mathrm{NaOH}$ to 7.4 ) at $37^{\circ} \mathrm{C}$ until clear to completely flush out blood. The perfusion was then quickly replaced by the enzyme solution containing $50 \mathrm{~mL}$ of buffer $\mathrm{A}$ and $25 \mathrm{mg}$ type II collagenase (Gibco, Carlsbad, CA), $10 \mathrm{mg}$ protease E, 25 mg BDM (Sigma, St Louis, MO, USA), $20 \mathrm{mg}$ carnitine, $31 \mathrm{mg}$ taurine, and $20 \mathrm{mg} \mathrm{L}$-glutamic acid for $20 \mathrm{~min}$. The enzymes were washed out by perfusion with $50 \mathrm{~mL}$ of buffer A solution. The heart was sectioned into 8-10 pieces, and the ventricles were cut into tissue as small as possible using an ophthalmic scissor in $30 \mathrm{~mL}$ of Kraft-Brühe (KB) solution, which contained (in mmol/L) $80 \mathrm{KOH}, 30 \mathrm{KCl}, 50 \mathrm{~L}$-glutamic acid, $1 \mathrm{MgCl}_{2}, 10$ HEPES, 10 glucose, $20 \mathrm{KH}_{2} \mathrm{PO}_{4}$, 20 taurine, and 0.5 EGTA ( $\mathrm{pH}$ adjusted to 7.3 with $\mathrm{KOH}$ ). The solution was blown gently with a pipette to separate the cells from the myocardial fragments and to obtain single ventricular myocytes. The cells were filtrated with a nylon filter (pore size: $200 \mu \mathrm{m}$ ) and resuspended in $30 \mathrm{~mL}$ of $\mathrm{KB}$ solution at $25^{\circ} \mathrm{C}$. Different volumes of $\mathrm{KB}$ and $\mathrm{CaCl}_{2}(1 \mathrm{mmol} / \mathrm{L})$ were added into the cell fluid five times until the calcium concentration was gradually restored to $1.8 \mathrm{mmol} / \mathrm{L}$. The cells were incubated for $24 \mathrm{~h}$ in the absence and presence of trapidil $(1 \mathrm{mmol} / \mathrm{L})$ and TMCC (0.01, 0.1, and $1 \mathrm{mmol} / \mathrm{L})$ for AP measurements.

The transfected HEK293 cell line that stably expressed human $I_{\mathrm{Ks}}$ was established with KCNQ1 (a-submit of $I_{\mathrm{Ks}}$ channel) and KCNE1 ( $\beta$-submit of $I_{\mathrm{Ks}}$ channel). The HEK293 cell line was purchased by Ice Bioscience Co Ltd (Beijing, China).

HEK293 cells stably expressing the $I_{\mathrm{Ks}}$ channel were cultured in Dulbecco's modified Eagle's medium supplemented with $10 \%$ fetal bovine serum, $0.8 \mathrm{mg} / \mathrm{mL}$ G 418 , and $0.2 \mathrm{mg} / \mathrm{mL}$ hygromycin B. Cells were grown in a humidified incubator at $37{ }^{\circ} \mathrm{C}$ under $5 \% \mathrm{CO}_{2}$. The cells were passaged by removing the medium and rinsing once with phosphate-buffered saline, followed by the addition of $2 \mathrm{~mL}$ of TrypLE ${ }^{\mathrm{TM}}$ Express solution. The plate was placed in a $37^{\circ} \mathrm{C}$ incubator for $5 \mathrm{~min}$. As soon as the cells detached, $9 \mathrm{~mL}$ of $37^{\circ} \mathrm{C}$ pre-warmed com- plete medium was added. The cell suspension was aspirated into a sterile pipette to gently dissociate cell aggregates. The cells were maintained by seeding $3 \times 10^{5}$ cells in a $100-\mathrm{mm}$ dish (final medium volume: $10 \mathrm{~mL}$ ) for routine maintenance. For the manual patch clamp test, $3 \times 10^{3}$ cells were seeded into a 24-well plate (final medium volume: $500 \mu \mathrm{L}$ ) with one coverslip in each well and tested $24 \mathrm{~h}$ after incubation at $37^{\circ} \mathrm{C}$ under $5 \% \mathrm{CO}_{2}$. To maintain electrophysiological performances, the cell density must not exceed $80 \%$. The cells were incubated for $24 \mathrm{~h}$ in the absence and presence of trapidil $(1 \mathrm{mmol} / \mathrm{L})$ and $\operatorname{TMCC}(0.01,0.1$, and $1 \mathrm{mmol} / \mathrm{L})$ for $I_{\mathrm{Ks}}$ measurements.

\section{Electrophysiological recordings}

The electrophysiological recordings were obtained under visual control under a microscope using the standard wholecell patch clamp technique. An EPC10 amplifier (HEKA Electronic, Lambrecht, Germany) was used to record the electrophysiological signal. Glass capillaries (BF 150-86-10, Sutter Instrument $\mathrm{Co}$, Novato, CA, USA) were drawn into patchtype glass microelectrodes using a micropipette puller (P97, Sutter Instrument Co, Novato, CA, USA). Microelectrode manipulators (MP285, Sutter Instrument Co, Novato, CA, USA) were operated on an inverted microscope (IX71, Olympus Co, Tokyo, Japan) to contact the recording electrodes to the cells, and a negative pressure was applied to form a 2-4 $\mathrm{G} \Omega$ Seal. Offset potentials were nulled directly before the formation of a seal. No leak subtraction was performed. Fast capacitance (in $\mathrm{pF}$ ) compensation was performed after a high seal was achieved. Cell capacitance (in $\mathrm{pF}$ ) compensation was performed from whole-cell capacitance compensation after the whole cell mode was achieved. The data were stored and analyzed with Patchmaster and Igor Pro (HEKA Electronic).

For $I_{\mathrm{Ks}}$ recordings, the extracellular solution contained (in $\mathrm{mmol} / \mathrm{L}) 140 \mathrm{NaCl}, 2.5 \mathrm{KCl}, 1 \mathrm{MgCl}_{2}, 2 \mathrm{CaCl}_{2}, 5$ glucose, and 10 HEPES; the $\mathrm{pH}$ was adjusted with $\mathrm{NaOH}$ to 7.4. The internal pipette solution consisted of (in mmol/L) $120 \mathrm{~K}$-aspartic, 5 $\mathrm{MgCl}_{2}, 5$ EGTA, 10 HEPES, $4 \mathrm{Na}_{2}$-ATP, $0.3 \mathrm{Na}_{2}$-GTP, 14 phosphocreatine disodium salt, and $20 \mathrm{U} / \mathrm{mL}$ creatine phosphokinase; the $\mathrm{pH}$ was adjusted with $\mathrm{KOH}$ to 7.2.

HEK293 cells were depolarized from a holding potential of $-30 \mathrm{mV}$ to various pre-pulse potentials of $-40 \mathrm{mV}$ to $+60 \mathrm{mV}$ for $5000 \mathrm{~ms}$ and repolarized to $-40 \mathrm{mV}$ for $2500 \mathrm{~ms}$ to evoke outward $I_{\mathrm{K} \text {-tail }}$ currents. Since the current measured under the whole-cell configuration was the sum of the whole cell current, the larger the cell volume, the greater the total current. To eliminate the difference in cell volume, current densities $(\mathrm{pA} / \mathrm{pF})$, which were calculated as current $(\mathrm{pA})$ divided by cell capacitance $(\mathrm{pF})$, were used as an index to show the size of the membrane current. All experiments were performed at room temperature.

\section{Action potential recording}

After the whole cell-recording mode was established, action potential (AP) was recorded with the current mode. AP was elicited by $5 \mathrm{~ms}$ current pulses, from $0 \mathrm{pA}$ to $3 \mathrm{nA}$, in $10 \mathrm{mV}$ increments. The extracellular solution contained (in mmol/L) 
$140 \mathrm{NaCl}, 3.5 \mathrm{KCl}, 2 \mathrm{CaCl}_{2}, 1 \mathrm{MgCl}_{2}, 10$ HEPES, 10 glucose, and $1.25 \mathrm{NaH}_{2} \mathrm{PO}_{4}$; the $\mathrm{pH}$ was adjusted with $\mathrm{NaOH}$ to 7.4. The internal pipette solution consisted of (in mmol/L) $5 \mathrm{NaCl}$, $140 \mathrm{~K}$-gluconate, $10 \mathrm{HEPES}, 1 \mathrm{MgCl}_{2}$, 1 EGTA, $2 \mathrm{Mg}$-ATP, and $0.1 \mathrm{CaCl}_{2}$; the $\mathrm{pH}$ was adjusted with $\mathrm{KOH}$ to 7.2. The effects of different concentrations of the drug $[1 \mathrm{mmol} / \mathrm{L}$ trapidil with/ without TMCC $0.01,0.1$, and $1 \mathrm{mmol} / \mathrm{L}]$ ) were recorded after stable recording for $10 \mathrm{~min}$. The parameters of resting membrane potential (RMP), action potential amplitude (APA), and action potential duration at $50 \%$ and $90 \%$ of repolarization $\left(\mathrm{APD}_{50}\right.$ and $\left.\mathrm{APD}_{90}\right)$ were estimated.

\section{Data analysis}

All data are expressed as the means \pm standard error of mean (SEM), and $\mathrm{n}$ indicates the number of cells or hearts studied. All data analyses were performed using GraphPad Prism 6.0 (GraphPad Software, La Jolla, CA, USA). OriginPro 8.0 and Inkscape 0.48.4.0 were used to draw the graphs. A one-way analysis of variance (ANOVA) or $t$-test was applied to determine the differences between means. If a significant difference was indicated by ANOVA, the least-significant difference method was used for multiple comparisons to determine the homogeneity of variance, or the rank sum test was used to determine the heterogeneity of variance. Differences were considered significant or highly significant at $P<0.05$ or $P<0.01$.

\section{Results}

Effects of TMCC (1, 2, and $4 \mathrm{mmol} / \mathrm{L})$ on ECG parameters in the normal and SQT2 model of isolated perfused heart from guinea pigs

As shown in Table 1, compared to the control groups, TMCC (1, 2, and $4 \mathrm{mmol} / \mathrm{L})$ extended the QT interval 5.25\% $\pm 1.28 \%$, $9.87 \% \pm 1.37 \%$, and $12.26 \% \pm 0.96 \%$, respectively (all $P<0.01$ vs control). TMCC $(1,2$, and $4 \mathrm{mmol} / \mathrm{L})$ also lengthened the $\mathrm{QT}_{\text {peak }}$ from $123.33 \pm 6.12$ to $131.93 \pm 6.26 \mathrm{mV}$, from $121.93 \pm 6.94$ to $139.83 \pm 5.98 \mathrm{mV}$, and from $129.40 \pm 6.83$ to $143.17 \pm 5.93$ $\mathrm{mV}$, respectively (all $P<0.01$ vs control). TMCC $(1,2$, and 4 $\mathrm{mmol} / \mathrm{L}$ ) did not change the value of rTp-Te (all $P>0.05$ vs control).

Pinacidil $(20 \mu \mathrm{mol} / \mathrm{L})$ was used to simulate the SQT2 model. From Figure 2, pinacidil significantly shortened the QT interval $(164.53 \pm 3.64 \mathrm{mV}$ vs $178.10 \pm 5.22 \mathrm{mV}, 146.12 \pm 3.21$

Table 1. Effects of $\operatorname{TMCC}(1,2$, and $4 \mathrm{mmol} / \mathrm{L})$ on ECG parameters on isolated hearts of guinea pig. ${ }^{* *} P<0.01$ vs control. Data are presented as the mean \pm SEM $(n=6)$.

\begin{tabular}{llll}
\hline \multicolumn{1}{c}{ Group } & \multicolumn{1}{c}{ QT $(\mathrm{ms})$} & $\mathrm{QT}_{\text {peak }}(\mathrm{ms})$ & $\mathrm{rTp}-\mathrm{Te}(\%)$ \\
\hline Control & $174.98 \pm 3.23$ & $123.33 \pm 6.12$ & $28.08 \pm 1.96$ \\
TMCC $(1 \mathrm{mmol} / \mathrm{L})$ & $184.38 \pm 5.13^{* *}$ & $131.93 \pm 6.26^{* *}$ & $26.95 \pm 1.77$ \\
Control & $172.97 \pm 4.80$ & $121.93 \pm 6.94$ & $27.08 \pm 1.78$ \\
TMCC $(2 \mathrm{mmol} / \mathrm{L})$ & $190.08 \pm 6.00^{* *}$ & $139.83 \pm 5.98^{* *}$ & $26.48 \pm 1.54$ \\
Control & $173.56 \pm 4.03$ & $129.40 \pm 6.83$ & $27.86 \pm 0.97$ \\
TMCC (4 mmol/L) & $194.76 \pm 4.41^{* *}$ & $143.17 \pm 5.93^{* *}$ & $26.00 \pm 1.55$ \\
\hline
\end{tabular}

QT, QT interval; rTp-Te, Tp-Te/QT ratio.
$\mathrm{mV}$ vs $156.17 \pm 4.22 \mathrm{mV}, 143.67 \pm 1.99 \mathrm{mV}$ vs $162.50 \pm 2.18 \mathrm{mV}$, respectively, $P<0.05$ vs control) and $\mathrm{QT}_{\text {peak }}(99.23 \pm 5.62 \mathrm{mV}$ vs $128.17 \pm 7.50 \mathrm{mV}, 82.10 \pm 7.60 \mathrm{mV}$ vs $98.10 \pm 7.25 \mathrm{mV}, 85.20 \pm 4.13$ vs $111.53 \pm 4.91 \mathrm{mV}$, respectively, $P<0.01$ vs control). This decrease was paralleled by a comparable increase in rTp-Te by $26.52 \% \pm 8.56 \%, 20.61 \% \pm 7.50 \%$, and $21.66 \% \pm 4.35 \%$, respectively $(P<0.05$ vs control). Subsequent additional perfusion with TMCC $(1,2$, and $4 \mathrm{mmol} / \mathrm{L})$ led to a significant increase of QT interval $(6.87 \% \pm 0.88 \%, 8.83 \% \pm 1.99 \%$, and $15.47 \% \pm 1.86 \%$, respectively, all $P<0.01$ vs pinacidil) and $\mathrm{QT}_{\text {peak }}(14.41 \% \pm 1.93 \%$, $14.27 \% \pm 1.75 \%$, and $24.67 \% \pm 3.80 \%$, respectively, all $P<0.01$ vs pinacidil). TMCC $(1,2$, and $4 \mathrm{mmol} / \mathrm{L})$ also reversed the value of rTp-Te to the normal range $(32.05 \% \pm 3.40 \%$ vs $36.28 \% \pm 3.22 \%$, $P<0.01 ; 38.72 \% \pm 3.95 \%$ vs $42.19 \% \pm 4.36 \%, P<0.05 ; 36.76 \% \pm 2.41 \%$ vs $41.24 \% \pm 2.94 \%, P<0.05$; all vs pinacidil, respectively) compared with pinacidil treatment alone.

Effects of TMCC (1, 2, and $4 \mathrm{mmol} / \mathrm{L})$ on the instability of RR and QT interval in the SQT2 model of the isolated perfused heart from guinea pig

RR or QT interval instability can be used to predict the occurrence of VF. To calculate the RR and QT repolarization instability, we used a new method reported by van der Linde et al ${ }^{[27]}$ to calculate total instability (TI), long-term instability (LTI), and short-term instability (STI) through the center of gravity (cg) of 30 coordinate points. The specific methods were as follows:

To analyze the total instability of the RR interval $\left(\mathrm{TI}_{\mathrm{RR}}\right)$, longterm instability of RR interval ( $\left.\mathrm{LTI}_{\mathrm{RR}}\right)$, and short-term instability of $\mathrm{RR}$ interval $\left(\mathrm{STI}_{\mathrm{RR}}\right)$, the following equations were used: $\operatorname{cg}(\mathrm{x})=\sum_{\mathrm{i}=\mathrm{m}}^{\mathrm{m}+30}\left(\mathrm{RR}_{\mathrm{i}}\right) / 30, \mathrm{cg}(\mathrm{y})=\sum_{\mathrm{i}=\mathrm{m}+1}^{\mathrm{m}+31}\left(\mathrm{RR}_{\mathrm{i}}\right) / 30$,

$$
\mathrm{TI}_{\mathrm{n}}=\sqrt{\left(\operatorname{cg}(\mathrm{x})-\mathrm{RR}_{\mathrm{n}}\right)^{2}+\left(\operatorname{cg}(\mathrm{y})-\mathrm{RR}_{\mathrm{n}+1}\right)^{2}}, \quad \mathrm{TI}=\overline{\mathrm{TI}_{\mathrm{n}}},
$$

To calculate the length and width of each point in the Poincaré plots (LTI and STI), as shown in Figure 3A, the original data point was rotated by $-45^{\circ}$ to calculate the horizontal and vertical coordinates of the original point relative to the diagonal (the dashed line in Figure 3A, which is the x-axis). The center of gravity after rotation was as follows:

$$
\begin{aligned}
& \text { Rotated } \operatorname{cg}(\mathrm{x}): \operatorname{Rcg}(\mathrm{x})=\cos \theta \times \operatorname{cg}(\mathrm{x})-\sin \theta \times \operatorname{cg}(\mathrm{y}), \\
& \text { Rotated } \operatorname{cg}(\mathrm{y}): \operatorname{Rcg}(\mathrm{y})=\sin \theta \times \operatorname{cg}(\mathrm{x})+\cos \theta \times \operatorname{cg}(\mathrm{y}), \theta=-45^{\circ} \\
& \text { Thus, } \mathrm{LTI}_{\mathrm{n}}=\left|\operatorname{Rcg}(\mathrm{x})-\left(\left(\cos \theta \times \mathrm{RR}_{\mathrm{n}+1}\right)-\left(\sin \theta \times \mathrm{RR}_{\mathrm{n}}\right)\right)\right|, \mathrm{LTI}= \\
& {\overline{\mathrm{LTI}_{n}}}_{\mathrm{n}} \\
& \mathrm{STI}_{\mathrm{n}}=\left|\operatorname{Rcg}(\mathrm{y})-\left(\left(\sin \theta \times \mathrm{RR}_{\mathrm{n}+1}\right)-\left(\cos \theta \times \mathrm{RR}_{\mathrm{n}}\right)\right)\right|, \mathrm{STI}=\overline{\mathrm{STI}}_{\mathrm{n}} .
\end{aligned}
$$

Pinacidil significantly increased the $\mathrm{TI}_{\mathrm{RR}}, \mathrm{STI}_{\mathrm{RR}}$, total instability of QT interval $\left(\mathrm{TI}_{\mathrm{QT}}\right)$, and short-term instability of QT interval $\left(\mathrm{STI}_{\mathrm{QT}}\right)$ (all $P<0.05$ vs control; Table 2$)$. All of these parameters were reversed to the normal range by TMCC treatment $(1,2$, and $4 \mathrm{mmol} / \mathrm{L} ; P<0.05$ vs pinacidil), except that TMCC $(1 \mathrm{mmol} / \mathrm{L})$ did not affect $\mathrm{STI}_{\mathrm{RR}}$ and $\mathrm{TI}_{\mathrm{QT}}(P>0.05)$. Pinacidil also raised the levels of long-term instability of RR interval $\left(\mathrm{LTI}_{\mathrm{RR}}\right)$ and long-term instability of QT interval $\left(\mathrm{LTI}_{\mathrm{QT}}\right)$, but not all groups showed significant differences vs the control. The 
A

Control

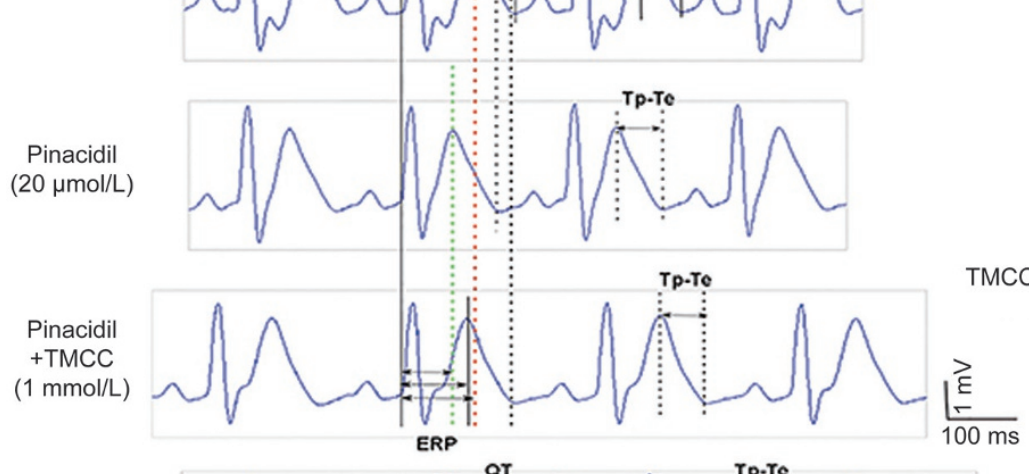

B

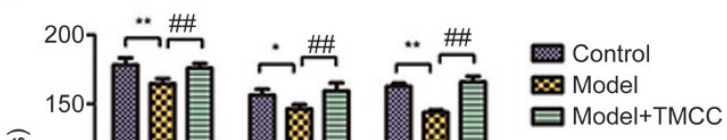

Model+TMCC
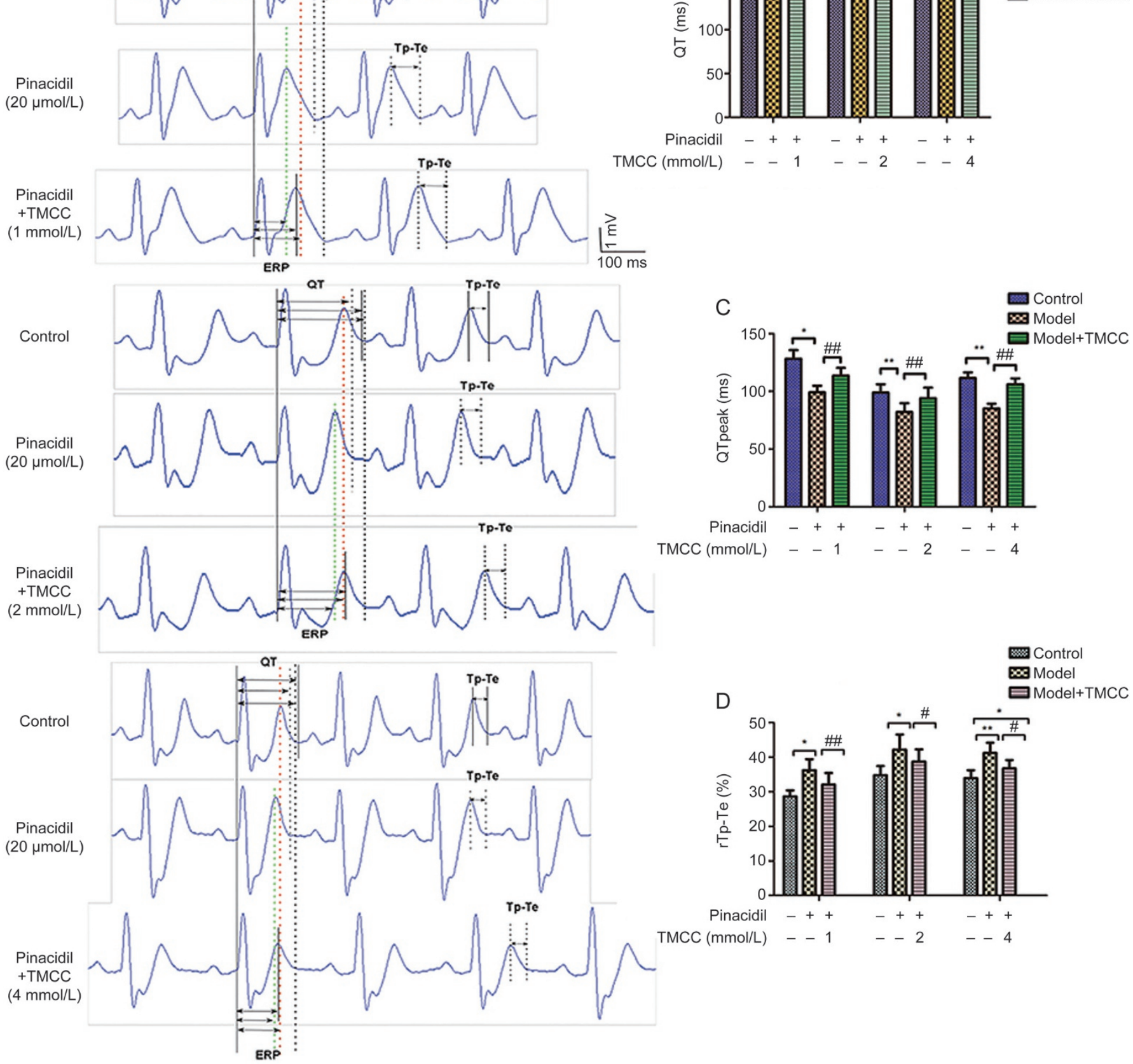

Figure 2. Effects of $\operatorname{TMCC}(1,2$, and $4 \mathrm{mmol} / \mathrm{L})$ on the electrocardiogram (ECG) parameters in the type 2 short QT syndrome (SQT2) model of the isolated perfused hearts from guinea pigs. Pinacidil $(20 \mu \mathrm{mol} / \mathrm{L})$ was used to simulate the SQT2 model. (A) ECG waveform in the absence and presence of pinacidil and TMCC. (B-D) Changes of $Q T, \mathrm{QT}_{\text {peak }}$ and $\mathrm{rT}_{\mathrm{p}}-\mathrm{T}_{\mathrm{e}}$ during the experiment. QT, QT interval; $\mathrm{QT}_{\text {peak }}$, the interval from Q-wave to T-wave peak; $r \mathrm{r}_{\mathrm{p}}$ $\mathrm{T}_{\mathrm{e}}, \mathrm{T}_{\mathrm{p}}-\mathrm{T}_{\mathrm{e}} / \mathrm{QT}$ ratio. Data are presented as the means \pm standard error of mean (SEM; $n=6$ ). ${ }^{*} P<0.05,{ }^{* *} P<0.01$ vs control. ${ }^{\#} P<0.05$, ${ }^{\# \#} P<0.01$ vs Pinacidil.

results are shown in Table 2 and Figure 3B-3G.

Effects of TMCC $(0.01,0.1$, and $1 \mathrm{mmol} / \mathrm{L})$ on AP in the trapidilinduced SQT2 model of ventricular myocytes from guinea pig APs were recorded in the current mode. All guinea pig ventricular myocytes were incubated for $24 \mathrm{~h}$ with and/or with- out drugs. The APs of myocytes were recorded in the absence (control group) and presence of $1 \mathrm{mmol} / \mathrm{L}$ trapidil (trapidil group) and in the presence of $1 \mathrm{mmol} / \mathrm{L}$ trapidil+TMCC $(0.01$, 0.1 , and $1 \mathrm{mmol} / \mathrm{L}$; Figure $4 \mathrm{~A})$. Both trapidil and TMCC $(0.01,0.1$, and $1 \mathrm{mmol} / \mathrm{L}$ ) had no effects on resting membrane potential (RMP) and action potential amplitude (APA) $(P>0.05$ 
A
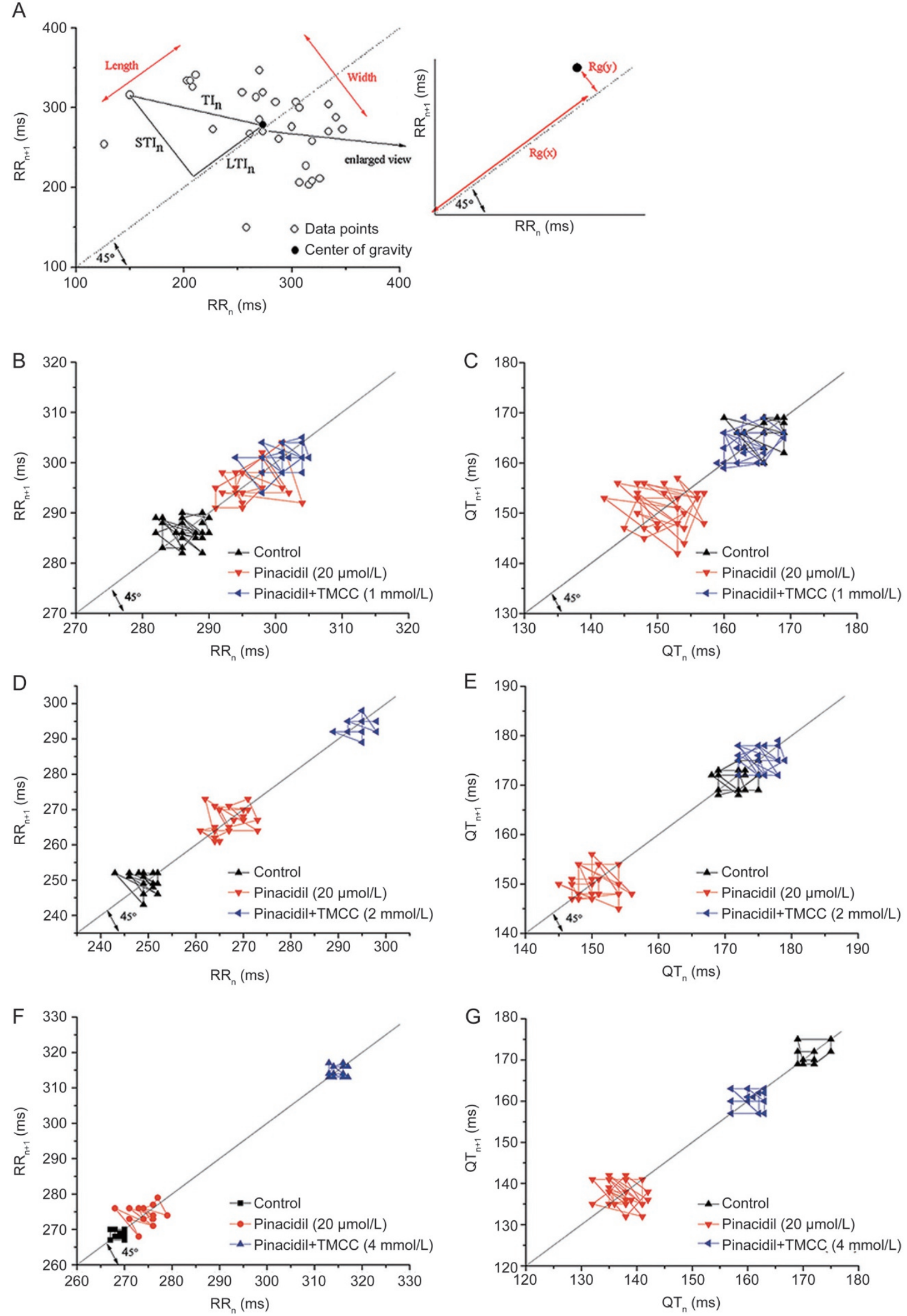

Figure 3. Poincare plots obtained from guinea pigs under the influence of various drugs. (A) The method to calculate the length and width of each point in the Poincaré plots (LTI and STI). (B-G) Effects of TMCC (1, 2, and $4 \mathrm{mmol} / \mathrm{L})$ on the instability of RR and QT interval in the SQT2 model of the isolated perfused heart from guinea pig. Pinacidil $(20 \mu \mathrm{mol} / \mathrm{L})$ was used to simulate the SQT2 model. $n=30$. 
Table 2. Effects of TMCC (1, 2, and $4 \mathrm{mmol} / \mathrm{L})$ on the instability of RR and QT interval in the SQT2 model of the isolated perfused heart from guinea pig.

\begin{tabular}{|c|c|c|c|c|c|c|c|}
\hline $1 \mathrm{mmol} / \mathrm{L}$ TMCC group & 6 & & & & & & \\
\hline Pinacidil $(20 \mu \mathrm{mol} / \mathrm{L})$ & & $3.83 \pm 0.18^{* *}$ & $2.28 \pm 0.12^{*}$ & $2.55 \pm 0.17^{*}$ & $3.83 \pm 0.32^{*}$ & $2.46 \pm 0.26^{*}$ & $2.34 \pm 0.21$ \\
\hline Pinacidil+TMCC (1 mmol/L) & & $3.14 \pm 0.20^{\#}$ & $1.83 \pm 0.14$ & $2.17 \pm 0.18$ & $3.42 \pm 0.20$ & $1.69 \pm 0.19^{\#}$ & $2.45 \pm 0.16^{*}$ \\
\hline $2 \mathrm{mmol} / \mathrm{L}$ TMCC group & 6 & & & & & & \\
\hline Pinacidil+TMCC (2 mmol/L) & & $2.28 \pm 0.09^{\# \#}$ & $1.16 \pm 0.10^{\# \#}$ & $1.61 \pm 0.09$ & $2.89 \pm 0.19^{\#}$ & $1.65 \pm 0.16^{\#}$ & $2.00 \pm 0.09$ \\
\hline $4 \mathrm{mmol} / \mathrm{L}$ TMCC group & 6 & & & & & & \\
\hline Control & & $1.97 \pm 0.13$ & $0.71 \pm 0.19$ & $1.58 \pm 0.07$ & $1.80 \pm 0.25$ & $0.61 \pm 0.19$ & $1.43 \pm 0.19$ \\
\hline Pinacidil $(20$ umol/L) & & $2.99 \pm 0.11^{* *}$ & $1.82 \pm 0.15^{* *}$ & $1.92 \pm 0.16$ & $3.59 \pm 0.37^{* *}$ & $2.22 \pm 0.28^{* *}$ & $2.30 \pm 0.24^{*}$ \\
\hline Pinacidil+TMCC (4 mmol/L) & & $1.65 \pm 0.36^{\# \#}$ & $0.77 \pm 0.25^{\# \#}$ & $1.22 \pm 0.21^{\# \#}$ & $2.41 \pm 0.45^{\#}$ & $1.15 \pm 0.43^{\#}$ & $1.70 \pm 0.20$ \\
\hline
\end{tabular}

TMCC, Taurine-Magnesium Coordination Compound; $\mathrm{TI}_{\mathrm{RR}}$, total instability of RR interval; $\mathrm{LTI}_{\mathrm{RR}}$, long-term instability of RR interval; STI $\mathrm{RR}_{\mathrm{R}}$, short-term instability of RR interval; $\mathrm{TI}_{\mathrm{QT}}$, total instability of QT interval; $\mathrm{LTI}_{\mathrm{QT}}$, long-term instability of QT interval; $\mathrm{STI}_{\mathrm{QT}}$, short-term instability of QT interval. Data are presented as the mean \pm standard error of mean (SEM) $(n=6)$. ${ }^{*} P<0.05,{ }^{* *} P<0.01$ vs control. ${ }^{\#} P<0.05,{ }^{\# \#} P<0.01$ vs pinacidil.

vs control, $n=10$, respectively; Figure $4 \mathrm{~B}, 4 \mathrm{C})$. Compared to the control group, trapidil shortened $\mathrm{APD}_{50}$ and $\mathrm{APD}_{90}$ (from $297.30 \pm 13.01$ to $241.15 \pm 8.95 \mathrm{mV}$ and from $326.15 \pm 16.67 \mathrm{mV}$ to $274.54 \pm 7.00 \mathrm{mV}$, respectively $(P<0.05$ vs control, $n=10)$, which could be extended by TMCC $(0.01,0.1$, and $1 \mathrm{mmol} / \mathrm{L})$ to the normal range $(P<0.05$ vs trapidil, $n=10$; Figure $4 \mathrm{D}, 4 \mathrm{E})$.
Effects of TMCC on the current-voltage relationship of $\mathrm{I}_{\mathrm{Ks}}$ expressed in HEK293 cells

The voltage-pulse protocol of the whole-cell mode is shown in Figure 5A. HEK293 cells were incubated with TMCC (0.01, 0.1 , and $1 \mathrm{mmol} / \mathrm{L}$ ) for $24 \mathrm{~h}$. The current-voltage ( $I-V)$ curves in Figure 5B show that TMCC $(0.01,0.1$, and $1 \mathrm{mmol} / \mathrm{L})$ could
A

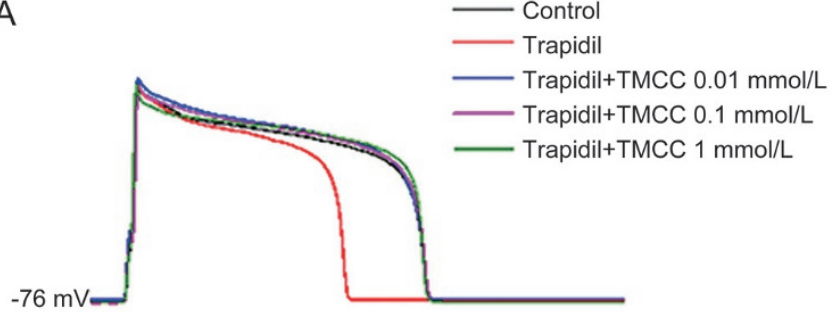

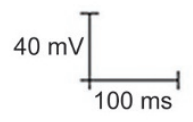

C

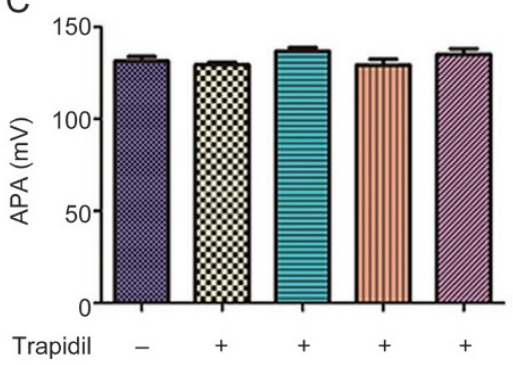

D

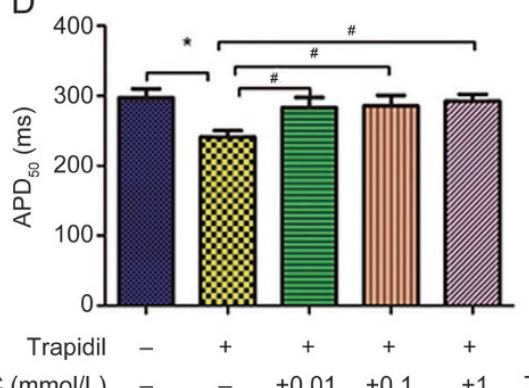

B

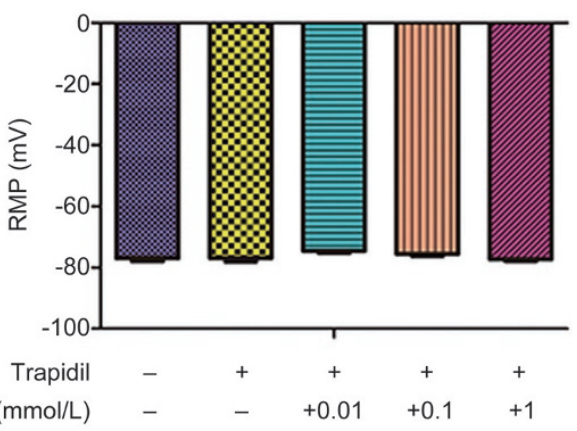

TMCC (mmol/L)

Figure 4. Effects of TMCC $(0.01,0.1$, and $1 \mathrm{mmol} / \mathrm{L})$ on the action potentials in the trapidil-induced SQT2 model of ventricular myocytes from guinea pig. (A) Action potentials of myocytes recorded in the absence (control group) and presence of $1 \mathrm{mmol} / \mathrm{L}$ trapidil (trapidil group) and in the presence of $1 \mathrm{mmol} / \mathrm{L}$ trapidil+TMCC $(0.01,0.1$, and $1 \mathrm{mmol} / \mathrm{L})$. (B and C) Summary of the effects of trapidil $(1 \mathrm{mmol} / \mathrm{L})$ with and without TMCC (0.01, 0.1 , and $1 \mathrm{mmol} / \mathrm{L}$ ) on the action potential duration at $50 \%$ repolarization $\left(\mathrm{APD}_{50}\right)$ and $90 \%$ repolarization level $\left(\mathrm{APD}_{90}\right)$. Data are presented as the means \pm standard error of mean (SEM; $n=10)$. ${ }^{*} P<0.05$ vs control. ${ }^{*} P<0.05$ vs trapidil. 
A

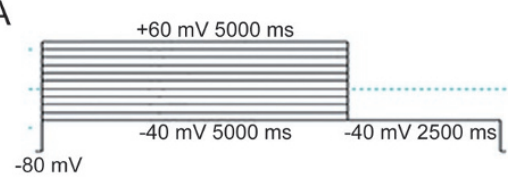

TMCC $0.01 \mathrm{mmol} / \mathrm{L}$

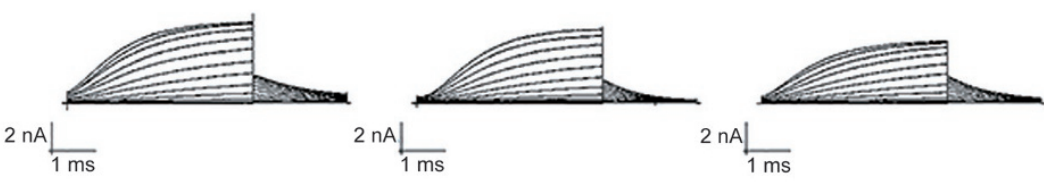

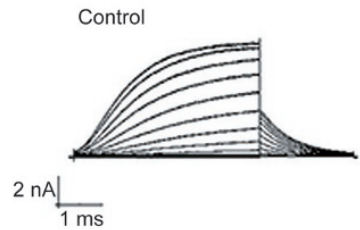

TMCC $1 \mathrm{mmol} / \mathrm{L}$

\section{B}

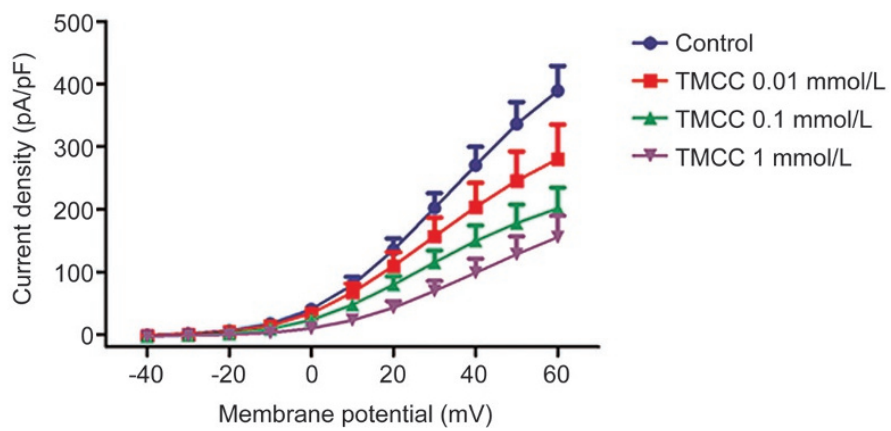

C
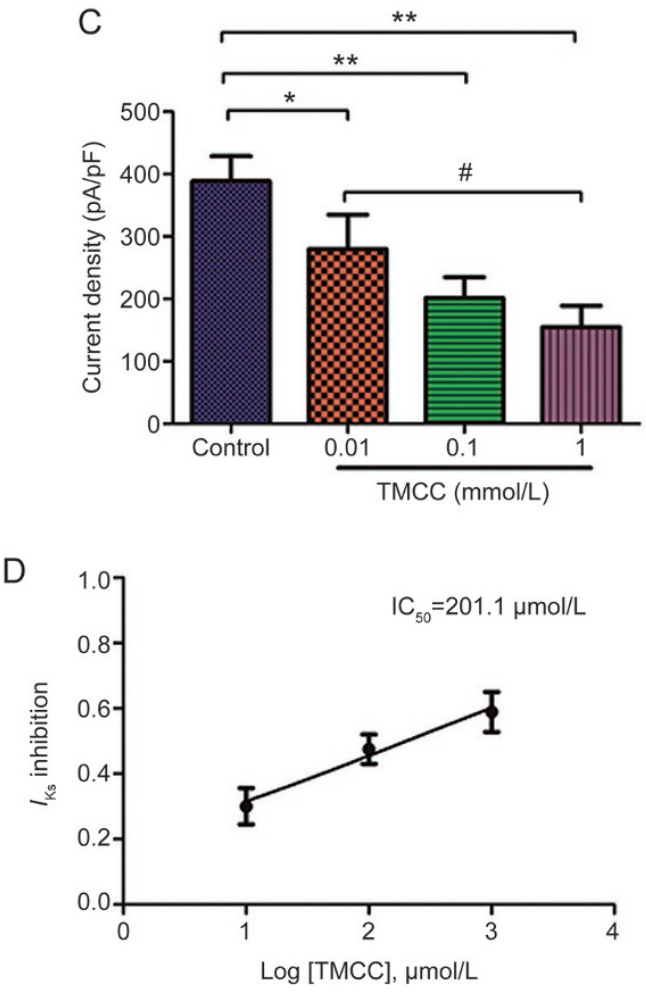

Figure 5. Effects of TMCC on the current-voltage relationship of $I_{\mathrm{Ks}}$ expressed in HEK293 cells. All cells were incubated for $24 \mathrm{~h}$ in the absence (control group) and in the presence of TMCC $(0.01,0.1$, and $1 \mathrm{mmol} / \mathrm{L})$. (A) The voltage-pulse protocol is shown above the current traces. $I_{\mathrm{Ks}}$ was elicited by voltage-clamp steps from a holding potential of $-40 \mathrm{mV}$ to $+60 \mathrm{mV}$ for $5 \mathrm{~s}$, and from a holding potential of $-40 \mathrm{mV}$ for $4 \mathrm{~s}$ to observe tail currents. (B) Effects of TMCC $(0.01,0.1$, and $1 \mathrm{mmol} / \mathrm{L})$ on the $I-V$ curves of $I_{\mathrm{Ks}}$. (C-D) TMCC-induced inhibition of $I_{\mathrm{Ks}}$. These results were observed at $+60 \mathrm{mV}$. Data are presented as the means $\pm \operatorname{SEM}(n=7) .{ }^{*} P<0.05,{ }^{* *} P<0.01$ vs control. ${ }^{*} P<0.05$ vs TMCC $(0.01 \mathrm{mmol} / \mathrm{L})$.

lower the $I-V$ curve and decrease the $I_{\mathrm{Ks}}$ current. The TMCCinduced inhibition of $I_{\mathrm{Ks}}$ was observed at a stimulation potential of $+60 \mathrm{mV}$, and this effect was dose dependent $\left(\mathrm{IC}_{50}=201.1\right.$ $\mu \mathrm{mol} / \mathrm{L}$; Figure 5C, 5D). The inhibition percentages of TMCC $(0.01,0.1$, and $1 \mathrm{mmol} / \mathrm{L})$ on $I_{\mathrm{Ks}}$ were $27.99 \%, 48.18 \%$, and $60.13 \%$, respectively $(P<0.05, P<0.01$, and $P<0.01$, respectively, all vs control).

Effects of TMCC $(0.01,0.1$, and $1 \mathrm{mmol} / \mathrm{L})$ on the current-voltage relationship of $I_{\mathrm{Ks}}$ and $I_{\mathrm{Ks}}$ current density in the trapidil-induced SQT2 model of HEK293 cells

The changes of $I_{\mathrm{Ks}}$ current density at the stimulation potential of $+60 \mathrm{mV}$ were observed after HEK293 cells were incubated with trapidil and TMCC $(0.01,0.1$, and $1 \mathrm{mmol} / \mathrm{L})$ for $24 \mathrm{~h}$. The whole-cell $I_{\mathrm{Ks}}$ traces are illustrated in Figure 6A. The $I-V$ curves in Figure 6B-6D show that compared to the control group, trapidil $(1 \mathrm{mmol} / \mathrm{L})$ could shift the $I-V$ curve up and increase the $I_{\mathrm{Ks}}$ current. However, TMCC $(0.01,0.1$, and 1 $\mathrm{mmol} / \mathrm{L}$ ) lowered the rising $I-V$ curve. TMCC could weaken the effect of trapidil on $I_{\mathrm{Ks}}$ current and reverse $I_{\mathrm{Ks}}$ to normal.

Compared with the control group, the $I_{\mathrm{Ks} \text {, tail }}$ current density of HEK293 cells incubated with $1 \mathrm{mmol} / \mathrm{L}$ trapidil for $24 \mathrm{~h}$ was significantly increased by $27.97 \% \pm 7.75 \%, 25.17 \% \pm 2.60 \%$, and $32.59 \% \pm 11.80 \%$, respectively, in each group $(n=7, P<0.05$ vs control). This upregulation of $I_{\mathrm{Ks}}$ by trapidil in the three groups was inhibited by TMCC $(0.01,0.1$, and $1 \mathrm{mmol} / \mathrm{L}$; by $19.92 \% \pm 7.91 \%, 27.06 \% \pm 2.96 \%$, and $34.73 \% \pm 9.81 \%$, respectively; all $P<0.05$ vs trapidil, $n=7$ ). The results are shown in Figure $6 \mathrm{E}$.

\section{Discussion}

SQTS is a newly discovered type of hereditary arrhythmia; little is known about the underlying gene mutation and epidemiology, and treatment options are limited.

This study demonstrated that TMCC therapy might have a protective effect on SQT2. The anti-arrhythmic effects of TMCC were comparable among the three models and were due to a significant increase in ventricular refractory periods. This may result from the decreasing effect of TMCC on $\mathrm{I}_{\mathrm{Ks}}$ currents.

The concentration of TMCC (from 0.01 to $4 \mathrm{mmol} / \mathrm{L}$ ) was different in models induced by pinacidil and trapidil because the mode of administration was different (acute perfusion in whole guinea pig heart and single-cell incubation for $24 \mathrm{~h}$, respectively). In previous studies on the effects of taurine, the dose of taurine ranged from $40 \mathrm{mmol} / \mathrm{L}$ (in a cell model) ${ }^{[28]}$ to $150 \mathrm{mg} / \mathrm{kg}$ (in an animal model) ${ }^{[29]}$. Furthermore, in the clinic, patients received $500 \mathrm{mg}$ taurine supplementation three times per day to evaluate the effectiveness of taurine on heart failure $^{[23]}$. Our previous studies had indicated that TMCC is non- 
A
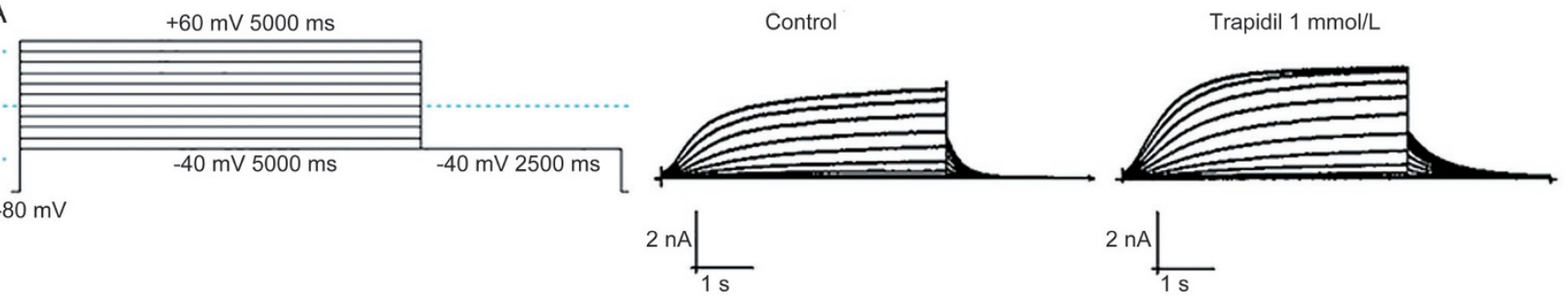

Trapidil $1 \mathrm{mmol} / \mathrm{L}+\mathrm{TMCC} 0.01 \mathrm{mmol} / \mathrm{L}$

Trapidil $1 \mathrm{mmol} / \mathrm{L}+\mathrm{TMCC} 0.1 \mathrm{mmol} / \mathrm{L}$

Trapidil $1 \mathrm{mmol} / \mathrm{L}+\mathrm{TMCC} 1 \mathrm{mmol} / \mathrm{L}$
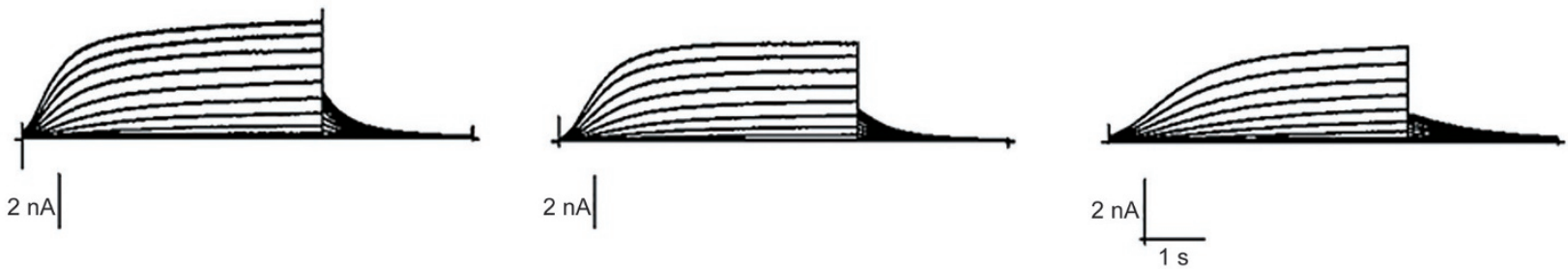

B

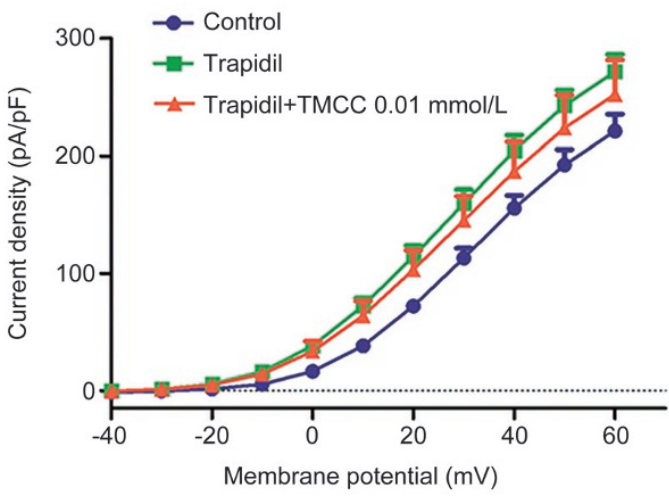

D

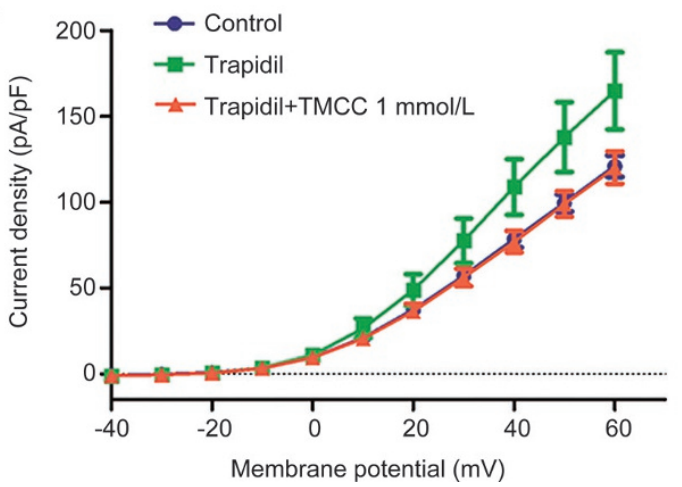

C

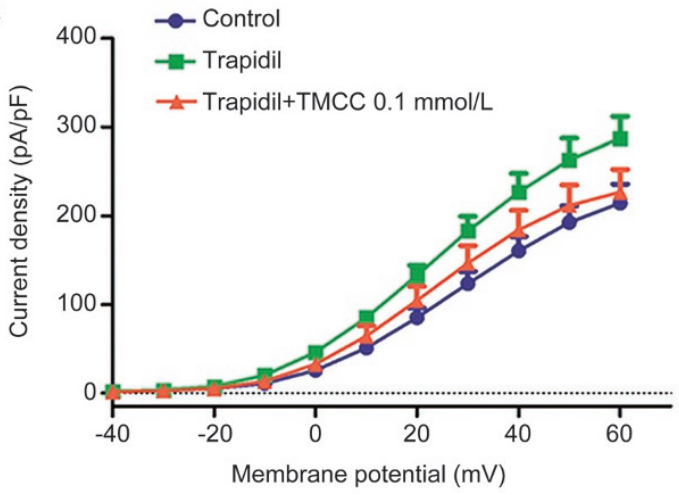

E

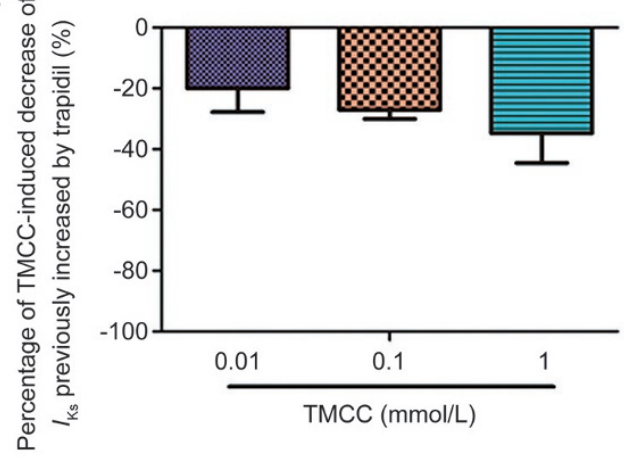

Figure 6. Effects of TMCC $(0.01,0.1$, and $1 \mathrm{mmol} / \mathrm{L})$ on the current-voltage relationship of $I_{\mathrm{Ks}}$ and $I_{\mathrm{Ks}}$ current density in the trapidil-induced SQT2 model of HEK293 cells. (A-D) Typical recordings obtained from a HEK293 cell stably expressing $I_{\text {KS }}$ channels in the absence (control group) and presence of 1 $\mathrm{mmol} / \mathrm{L}$ trapidil (Trapidil group) and in the presence of $1 \mathrm{mmol} / \mathrm{L}$ trapidil+TMCC $(0.01,0.1$, and $1 \mathrm{mmol} / \mathrm{L}$ ). The voltage-pulse protocol is shown above the current traces. $I_{\mathrm{Ks}}$ was elicited by voltage-clamp steps from a holding potential of $-40 \mathrm{mV}$ to $+60 \mathrm{mV}$ for $5 \mathrm{~s}$, from a holding potential of $-40 \mathrm{mV}$ for $4 \mathrm{~s}$ to observe tail currents. The voltage-pulse protocol is shown in the inset. (E) These results were observed at $+60 \mathrm{mV}$. Data are presented as the means \pm SEM $(n=7)$. Percentage of TMCC-induced decrease of $I_{\text {Ks }}$ previously increased by trapidil $(\%)=\left[\left(I_{\text {TMCc-treated }}-I_{\text {control }}\right)-\left(I_{\text {trap }}-I_{\text {control }}\right)\right] / I_{\text {control }} \times 100 \%$.

toxic. Therefore, the dosage in this experiment was suitable.

In this study, pinacidil and trapidil were used to establish a pharmacological model of SQT2. Pinacidil was applied to mimic the clinical SQT2 syndrome with a significant QT interval shortening and an increase in TDR. Our results were consistent with those of other studies that used pinacidil to simulate the SQTS model. In our study, trapidil was used to simulate the electrophysiological characteristics of SQT2 with an increased $I_{\mathrm{KS}}$ current and reduced APD and ventricular refractory periods, consistent with the results reported by 
Marumoto et al ${ }^{[22]}$.

The instability of the RR and QT interval is an important risk factor in the prediction of arrhythmia ${ }^{[30]}$. When the instability of RR and QT interval is increased, the ectopic exciting point is easily achieved, which might result in VF. VF is also a symptom of SQTS. In this study, pinacidil increased $\mathrm{TI}_{\mathrm{RR}}$, $\mathrm{STI}_{\mathrm{RR}}, \mathrm{TI}_{\mathrm{QT}}$, and $\mathrm{STI}_{\mathrm{QT}}$, which increased the risk of $\mathrm{VF}$. TMCC could decrease the instability of the RR and QT interval and hence exerted potent anti-arrhythmic effects.

The duration of the refractory period of the myocardium is correlated with ventricular arrhythmia. Gaita et al ${ }^{[2]}$ demonstrated that SQTS is characterized by sudden death and short refractory periods. When the ventricular myocyte refractory period is shortened, myocardium excitability is enhanced, resulting in ventricular premature systole and activation. In the ECG, the value of $\mathrm{QT}_{\text {peak }}$ represents the effective refractory period, which is equivalent to the $\mathrm{APD}_{50}$ of the action potential. In this study, the symptoms of SQTS with significantly shortened QT and $\mathrm{QT}_{\text {peak }}$ intervals induced by pinacidil and abbreviated $\mathrm{APD}_{50}$ and $\mathrm{APD}_{90}$ induced by trapidil could be reversed by $\mathrm{TMCC}$, which mediated a significant increase of ventricular refractory periods.

On the other hand, the elevation in TDR could increase the risk of ventricular arrhythmia and could be the basis of SQTS ${ }^{[31]}$. The value of $T_{p}-T_{e}$ represents the relative refractory period, which reflects TDR. While $\mathrm{T}_{\mathrm{p}}-\mathrm{T}_{\mathrm{e}}$ is susceptible to changes in the heart rate, it cannot eliminate the interference caused by the heart rate as to accurately predict arrhythmia. $\mathrm{rT}_{\mathrm{p}}-\mathrm{T}_{\mathrm{e}}$ is a more sensitive indicator of arrhythmia, as it can eliminate the mixed effect caused by the heart rate and individual QT interval variation ${ }^{[32]}$. TMCC could decrease the pinacidil-induced increase in TDR.

Apart from the shortened refractory period, increased TDR and instability of the RR and QT interval are indicators of arrhythmia propensity. TMCC exerted potent anti-arrhythmic effects in the SQT2 models by improving these indexes through its effects on ventricular repolarization.

The $I_{\mathrm{Ks}}$ channel plays an important role in ventricular repolarization. To explain the underlying mechanisms of TMCC's effectiveness on SQT2, we chose HEK293 cells that only stably expressed the $I_{\mathrm{Ks}}$ channel to avoid interference with other currents. Bellocq et al ${ }^{[33]}$ found that mutations in KCNQ1 led to a gain of function in $I_{\mathrm{Ks}}$, which is the hallmark of SQT2. $I_{\mathrm{Ks}}$ is widely distributed in human atrial myocytes, ventricular myocytes, and pacemaker cells, and it plays an important role in action potential repolarization in cardiomyocytes ${ }^{[34]}$. The trapidil-induced increase in $I_{\mathrm{Ks}}$ current was reversed to the normal range by TMCC-treatment $(0.01,0.1$, and $1 \mathrm{mmol} / \mathrm{L})$ in a concentration-dependent manner. We speculate that the effectiveness of TMCC in the treatment of SQT2 can be attributed to the blocking of $I_{\mathrm{Ks}}$. When $I_{\mathrm{Ks}}$ is blocked, the outward $\mathrm{K}^{+}$current decreases, which leads to a lengthened ventricular repolarization time. Further, it extends the APD and QT interval and alleviates the symptoms of SQT2.

Next, we investigated whether TMCC could affect the protein level of KCNQ1. Western blot analysis indicated that
TMCC $(0.01,0.1$, and $1 \mathrm{mmol} / \mathrm{L})$ did not influence the expression of KCNQ1 protein after $24 \mathrm{~h}$ (data not shown). Thus, TMCC had no effect on the gene level, suggesting that it is a mild drug.

Although the pinacidil- and trapidil-induced SQT2 models are different from the clinical syndromes that are described as genotypical SQT2, they have the same underlying SQT2 mechanism and may therefore provide insights into the underlying electrophysiological changes. To date, few studies have reported effective pharmacological treatments for SQT2. According to the latest report by Hancox et al ${ }^{[35]}$, ranolazine potentially has therapeutic value for the treatment of SQT2 and SQT3. However, Frommeyer et $a l^{[18]}$ demonstrated that the predominant anti-arrhythmic mechanism of ranolazine was most likely the inhibition of the fast component of the outward delayed rectifier potassium current $\left(I_{\mathrm{Kr}}\right)$, which corresponded to SQT1. The present study indicated that TMCC presents anti-arrhythmic effects on pharmacological models of SQT2 induced by pinacidil and trapidil in both whole-heart and single-cell models.

Our study has some limitations. In this study, guinea pig ventricular myocytes were used to simulate human ventricular electrophysiological action potentials; there are certain species differences. When the AP of guinea pig ventricular myocytes was measured, the endocardial, mid-myocardial, and epicardial ventricular myocytes were not separated. There are heterogeneities in the electrophysiological properties of ventricular myocytes. We used two different drugs (pinacidil and trapidil) to simulate SQT2 because preliminary experiments demonstrated that pinacidil could not commendably stimulate the $I_{\mathrm{Ks}}$ current. Further studies are warranted to investigate the effects of TMCC on a whole-animal SQT2 model.

\section{Conclusion}

This study demonstrates, for the first time in both an experimental whole-heart model and a single-cell model, that treatment with TMCC may have beneficial effects in extending the repolarization period and inhibiting the repolarizing current, $I_{\mathrm{Ks}}$. These results suggest that TMCC may be a reasonable therapeutic option for ventricular arrhythmia in SQT2.

\section{Acknowledgments}

The authors appreciate the valuable comments from other members of our laboratories. This study was supported by the National Natural Science Foundation of China (№ 81373410) and the Youth Project of Tianjin Natural Foundation, China (№ 14JCQNJC13700).

\section{Author contribution}

Jian-shi LOU, Meng-yao AN, Yi KANG, and Yong-qiang YIN designed research; Tao SUN provided TMCC; Meng-yao AN, Yan LI, Kai SUN and Ying-ying PAN performed the research; Wei-zhen GAO, Hong WU, and Ying-ying PAN contributed new reagents or analytic tools; Meng-yao AN and Kai SUN analyzed the data; and Meng-yao AN and Jian-shi LOU wrote the paper. 


\section{References}

1 Gussak I, Brugada P, Brugada J, Wright RS, Kopecky SL, Chaitman $\mathrm{BR}$, et al. Idiopathic short QT interval: a new clinical syndrome? Cardiology 2000; 94: 99-102.

2 Gaita F, Giustetto C, Bianchi F, Wolpert C, Schimpf R, Riccardi R, et al. Short QT syndrome: a familial cause of sudden death. Circulation 2003; 108: 965-70.

3 Rudic B, Schimpf R, Borggrefe M. Short QT syndrome-Review of diagnosis and treatment. Arrhyth Electrophysiol Rev 2014; 3: 76-9.

4 Hong K, Hu J, Yu J, Brugada R. Concomitant Brugada-like and short QT electrocardiogram linked to SCN5A mutation. Eur J Hum Genet 2012; 20: 1189-92.

5 Cheng TO. Digitalis administration: an underappreciated but common cause of short QT interval. Circulation 2004; 109: e152.

6 Tavernier R, Jordaens L, Haerynck F, Derycke E, Clement DL. Changes in the QT interval and its adaptation to rate, assessed with continuous electrocardiographic recordings in patients with ventricular fibrillation, as compared to normal individuals without arrhythmias. Eur Heart J 1997; 18: 994-9.

7 Malik M. Drug-induced QT/QTc interval shortening: lessons from druginduced QT/QTc prolongation. Drug Safety 2016; 39: 647-59.

8 Saikawa T, Tsumabuki S, Nakagawa M, Takakura T, Tamura M, Maeda T, et al. QT intervals as an index of high serum calcium in hypercalcemia. Clin Cardiol 1988; 11: 75-8.

9 Mondoly P, Cardin C, Rollin A, Duparc A, Maury P. Use of a subcutaneous ICD in a patient with short QT syndrome. Clin Case Rep 2016; 4: 35-8.

10 Patel C, Antzelevitch C. Pharmacological approach to the treatment of long and short QT syndromes. Pharmacol Ther 2008; 118: 138-51.

11 Schimpf R, Veltmann C, Giustetto C, Gaita F, Borggrefe M, Wolpert C. In vivo effects of mutant HERG $\mathrm{K}^{+}$channel inhibition by disopyramide in patients with a short QT-1 syndrome: a pilot study. J Cardiovasc Electrophysiol 2007; 18: 1157-60.

12 Chinushi M, Sato A, Izumi D, Furushima H. Nifekalant enlarged the transmural activation-recovery interval difference as well as the peakto-end interval on surface ECG in a patient with short-QT syndrome. J Cardiovasc Electrophysiol 2012; 23: 877-80.

13 Bun SS, Maury P, Giustetto C, Deharo JC. Electrical storm in shortQT syndrome successfully treated with Isoproterenol. J Cardiovasc Electrophysiol 2012; 23: 1028-30.

14 Bodi I, Franke G, Pantulu ND, Wu K, Perez-Feliz S, Bode C, et al. Differential effects of the beta-adrenoceptor blockers carvedilol and metoprolol on SQT1- and SQT2-mutant channels. J Cardiovasc Electrophysiol 2013; 24: 1163-71.

15 Milberg P, Tegelkamp R, Osada N, Schimpf R, Wolpert C, Breithardt $\mathrm{G}$, et al. Reduction of dispersion of repolarization and prolongation of postrepolarization refractoriness explain the antiarrhythmic effects of quinidine in a model of short QT syndrome. J Cardiovasc Electrophysiol 2007; 18: 658-64.

16 Padrini R, Bova S, Cargnelli G, Piovan D, Ferrari M. Effects of pinacidil on guinea-pig isolated perfused heart with particular reference to the proarrhythmic effect. Br J Pharmacol 1992; 105: 715-9.

17 Koncz I, Gurabi Z, Patocskai B, Panama BK, Szel T, Hu D, et al. Mechanisms underlying the development of the electrocardiographic and arrhythmic manifestations of early repolarization syndrome. J Mol Cell Cardiol 2014; 68: 20-8.

18 Frommeyer G, Ellermann C, Dechering DG, Kochhauser S, Bogeholz $\mathrm{N}$, Guner F, et al. Ranolazine and vernakalant prevent ventricular arrhythmias in an experimental whole-heart model of short QT syndrome. J Cardiovasc Electrophysiol 2016; 27: 1214-9.

19 Kijtawornrat A, Panyasing Y, Del Rio C, Hamlin RL. Assessment of ECG interval and restitution parameters in the canine model of short QT syndrome. J Pharmacol Toxicol Methods 2010; 61: 231-7.

20 Azuma J, Sawamura A, Harada H, Tanimoto T, Morita Y, Sperelakis N, et al. Trapidil stimulation of slow $\mathrm{Ca}^{2+}$ current in cardiac muscle. Eur J Pharmacol 1981; 72: 199-208.

21 Kotake H, Hisatome I, Miyamoto J, Igawa O, Mashiba H. Electrophysiological effect of trapidil on rabbit sinoatrial node cells. Arch Int Pharmacodyn Ther 1986; 279: 61-71.

22 Marumoto A, Hasegawa J, Zhang F, Moritani H, Harada T, Sano A, et al. Trapidil enhances the slowly activating delayed rectifier potassium current and suppresses the transient inward current induced by catecholamine in guinea pig ventricular myocytes. J Cardiovasc Pharmacol 2005; 46: 167-76.

23 Ahmadian M, Dabidi Roshan V, Ashourpore E. Taurine supplementation improves functional capacity, myocardial oxygen consumption, and electrical activity in heart failure. J Dietary Suppl 2017; 14: 422-32.

24 Standley CA, Batia L, Yueh G. Magnesium sulfate effectively reduces blood pressure in an animal model of preeclampsia. J Matern Fetal Neonatal Med 2006; 19: 171-6.

25 Zhao L, Lou J, Wu H, Yin Y, Kang Y. Effects of taurine-magnesium coordination compound on ionic channels in rat ventricular myocytes of arrhythmia induced by ouabain. Biol Trace Elem Res 2012; 147: 275-84.

26 Yin Y, Wen K, Wu Y, Kang Y, Lou J. Inhibition of sodium current by taurine magnesium coordination compound prevents cesium chlorideinduced arrhythmias. Biol Trace Elem Res 2012; 146: 192-8.

27 van der Linde H, Van de Water A, Loots W, Van Deuren B, Lu HR, Van Ammel K, et al. A new method to calculate the beat-to-beat instability of QT duration in drug-induced long QT in anesthetized dogs. J Pharmacol Toxicol Methods 2005; 52: 168-77.

28 Zhang Z, Zhao L, Zhou Y, Lu X, Wang Z, Wang J, et al. Taurine ameliorated homocysteine-induced $\mathrm{H} 9 \mathrm{C} 2$ cardiomyocyte apoptosis by modulating endoplasmic reticulum stress. Apoptosis 2017; 22: 647-61.

29 Chowdhury S, Sinha K, Banerjee S, Sil PC. Taurine protects cisplatin induced cardiotoxicity by modulating inflammatory and endoplasmic reticulum stress responses. BioFactors 2016; 42: 647-64.

30 Chen XZ, Tereshchenko LG, Berger RD, Trayanova NA. Arrhythmia risk stratification based on QT interval instability: An intracardiac electrocardiogram study. Heart Rhythm 2013; 10: 875-80.

31 Sicouri S, Glass A, Ferreiro M, Antzelevitch C. Transseptal dispersion of repolarization and its role in the development of Torsade de Pointes arrhythmias. J Cardiovasc Electrophysiol 2010; 21: 441-7.

32 Liu T, Brown BS, Wu Y, Antzelevitch C, Kowey PR, Yan GX. Blinded validation of the isolated arterially perfused rabbit ventricular wedge in preclinical assessment of drug-induced proarrhythmias. Heart Rhythm 2006; 3: 948-56.

33 Bellocq C, van Ginneken AC, Bezzina CR, Alders M, Escande D, Mannens MM, et al. Mutation in the KCNQ1 gene leading to the short QT-interval syndrome. Circulation 2004; 109: 2394-7.

34 Charpentier F, Merot J, Loussouarn G, Baro I. Delayed rectifier $\mathrm{K}^{+}$ currents and cardiac repolarization. J Mol Cell Cardiol 2010; 48: 37-44.

35 Hancox JC. Considering ranolazine as a potential treatment for $\mathrm{K}^{+}$ channel linked short QT syndrome. J Cardiovasc Electrophysiol 2016; 27: E5. 